\title{
Comment to Lira-Dale et al.: Effect of intraprostatic epinephrine on intraoperative blood loss reduction during transurethral resection of the prostate
}

\author{
Rohit Kathpalia $\cdot$ Swarnendu Mandal $\cdot$ \\ Apul Goel - S. N. Sankhwar
}

Received: 2 May 2012/ Accepted: 11 June 2012/Published online: 29 July 2012

(C) Springer Science+Business Media, B.V. 2012

\section{Dear Editor,}

We appreciate the authors for conducting this study on the effect of intraprostatic epinephrine on intraoperative blood loss reduction during transurethral resection of the prostate, but few points need clarification [1]. The authors have shown the benefits on intraoperative blood loss but do not mention whether intraprostatic epinephrine had any benefit in postoperative period. We assume that the vasoconstrictive effect of epinephrine can conceal the bleeding vessels intraoperatively that could have been coagulated and postoperatively as the effect weans off, these patients may have reactionary hemorrhage [2].

Is there any reason why the resected prostatic tissue was less in epinephrine group than the placebo group,

This comment refers to the article available at doi:10.1007/s11255-011-0071-2. An author's reply to this comment is available at doi:10.1007/s11255-012-0226-9.

R. Kathpalia ( $\varangle)$ - S. Mandal · A. Goel · S. N. Sankhwar Department of Urology, Chhatrapati Shahuji Maharaj Medical University (Erstwhile King George's Medical College), Lucknow 226003, Uttar Pradesh, India e-mail: drrohit.kathpalia@gmail.com

S. Mandal

e-mail: dr.swarnendu@gmail.com

A. Goel

e-mail: goelapul1@ rediffmail.com

S. N. Sankhwar

e-mail: sankhwarsn_sn@yahoo.com despite larger gland volume in the former? This can bias the results as the intraoperative blood loss is proportional to the resected tissue [3].

Finally, the amount of epinephrine injected into the prostate was fixed, that is, $20 \mathrm{ml}$. Probably, the effect may vary based on prostate volume, where smaller glands may require lesser dose in comparison with larger ones. We would like to have author's opinion in this context.

\section{References}

1. Lira-Dale A, Maldonado-Ávila M, Gil-García JF, MuesGuizar EH, Nerubay-Toiber R, Guzmán-Esquivel J, Delgado-Enciso I (2012) Effect of intraprostatic epinephrine on intraoperative blood loss reduction during transurethral resection of the prostate. Int Urol Nephrol 44:365-369

2. Schelin S, Claezon A, Sundin A, Wagrell L (2004) Effects of intraprostatic and periprostatic injections of mepivacaine epinephrine on intraprostatic blood flow during transurethral microwave thermotherapy: correlation with $[15 \mathrm{O}] \mathrm{H}_{2} \mathrm{O}-\mathrm{PET}$. J Endourol 18(10):965-970

3. Aus G, Bergdahl S, Hugosson J, Norlén L (1994) Volume determinations of the whole prostate and of adenomas by transrectal ultrasound in patients with clinically benign prostatic hyperplasia: correlation of resected weight, blood loss and duration of operation. Br J Urol 73(6):659-663 